\title{
Solen går ner över svensk socialdemokrati
}

\section{Göran Therborn}

SAMMANDRAG: Av rädsla inför ett förmodat än sämre resultat hälsade Socialdemokraterna resultatet i det svenska riksdagsvalet 2018 som en halv seger. SAP:s usla stöd bland väljarna, det lägsta sedan en nästan allmän manlig rösträtt infördes I9II, understryker det missnöje som drabbat socialdemokratins globala flaggskepp. I sin artikel, som skrevs före det att regeringsbildningen blev klar, kartlägger Göran Therborn bakgrunden till valresultatet genom att granska den av SAP ledda nyliberala omsvängningen av svensk politik sedan början av I980-talet, och uppgången för Sverigedemokraterna som politisk kraft i spåren av lågkonjunktur och flyktinginvandring. Till denna svenska översättning har Therborn fogat en kort efterskrift om den senaste utvecklingen efter januariavtalet 2019.

NYCKELORD: Socialdemokraterna; socialdemokrati; arbetarrörelse; riksdagsvalet 20I8; nyliberalism; migration; Sverigedemokraterna.

PUBLICERINGSHISTORIK: Översättning av en, av författaren, något reviderad och utvidgad version av artikeln "Twilight of Swedish Social Democracy" i New Left Review, nr II3 (2018).

GÖRAN THERBORN är professor emeritus i sociologi vid University of Cambridge.

E-POSTADRESS: gt274@cam.ac.uk

FÖRSLAG PÅ KÄLLANGIVELSE:

Therborn, Göran (20I9) "Solen går ner över svensk socialdemokrati”, i Arkiv. Tidskrift för sambällsanalys, nr IO, s. 7-32.

DOI: https://doi.org/IO.I3068/2000-62I7.IO.I

(C) original: Göran Therborn/New Left Review 20I8, https://newleftreview.org

(C) svensk version: Göran Therborn/Arkiv förlag \& tidskrift 2019

(publicerad I5 april 2019)

Artikeln distribueras enligt en upphovsrättslicens från Creative Commons:

Erkännande-Ickekommersiell-IngaBearbetningar 3.0 Unported, som medger fri ickekommersiell användning och spridning i oförändrat skick så länge källan anges. 
Arkiv. Tidskrift för samhällsanalys är en sakkunniggranskad vetenskaplig tidskrift för samhällsvetenskap och historia. Samtliga artiklar publiceras fritt tillgängliga på:

$$
\text { www.tidskriftenarkiv.se }
$$

Beständig länk, DOI: https://doi.org/IO.13068/2000-62I7

Den här artikeln finns tillgänglig i följande format:

PDF: via beständig länk, DoI: https://doi.org/IO.I3068/2000-62I7.IO.I

TRYCK: ingår i bokutgåva av numret, ISBN: 978 9I 79243272

Grafisk utformning och sidnumrering är identisk i pdf och tryck.

Samtliga artiklar i nr ıo (2019) nås via beständig länk, DOI: https://doi.org/IO.I3068/2000-6217.10

Arkiv. Tidskrift för samhällsanalys

ISSN: 2000-62I7 (för elektronisk resurs)

ISSN: 2000-6225 (för tryckta nummer)

ges ut av

Stiftelsen Arkiv för främjande och spridning av samhällsvetenskaplig och historisk forskning

genom

Arkiv förlag \& tidskrift

Box 1559

SE-22I OI Lund

BESÖK: L Gråbrödersg 3 c, ipg

TEL: 046-I3 3920

ARKIV FÖRLAG: arkiv@arkiv.nu·www.arkiv.nu

TIDSKRIFTEN ARKIV: red@tidskriftenarkiv.se.www.tidskriftenarkiv.se

ANSVARIg UTGIVARE \& CHEFREDAKTÖR: Sven Hort

AdMinistrativ Redaktör: David Lindberg

Redaktörer: Paavo Bergman, Per Dannefjord, Lisa Kings,

Zhanna Kravchenko, Anna-Maria Sarstrand Marekovic 


\title{
Solen går ner över svensk socialdemokrati
}

\author{
GÖRAN THERBORN
}

Riksdagsvalet den 9 september 2018 ledde till det svagaste resultatet för Socialdemokraterna sedan en nästan allmän manlig rösträtt infördes I9II. Då fick partiet 28,5 procent av rösterna, den här gången kom det upp till 28,3 procent. Ett helt århundrades valframgångar sopades bort. Ändå hälsade partihögkvarteret resultatet som en halv seger, och Stefan Löfven - en stadgad, medelålders familjeman - firade (med sin hustru) långt in på valnatten. Socialdemokraternas ambitioner har i dag blivit ganska blygsamma. Historiskt var Socialdemokratiska arbetarepartiet (SAP) det i särklass mest framgångsrika av världens arbetarpartier och socialdemokratiska partier. Under mer än ett halvt sekel, mellan 1932 och 1988, fick de mer än 40 procent av rösterna i varje val i ett system med proportionell representation, flermansvalkretsar och en rad konkurrerande partier. Inget annat svenskt parti har kommit över 30-procentsgränsen sedan första världskriget. Så sent som 1994 vann SAP mer än 45 procent av rösterna. Det styrde landet utan avbrott, utom för en semesterregering I936, från 1932 till 1976 och sedan igen under åren 1982-199I, 1994-2006 och 20I4-20I8. I skrivande stund kan man inte utesluta möjligheten att SAP kommer att dominera en koalition efter 2018.

Ursprungligen publicerad som "Twilight of Swedish Social Democracy" i New Left Review, nr II3 (2018) och artikeln skrevs således före januariavtalet 20I9. Till denna svenska översättning har Göran Therborn reviderat texten och fogat en kort efterskrift om den senaste utvecklingen. 
ARKIV | NR IO | VALET 2018

Största parti i Sveriges kommuner i riksdagsvalet 2018

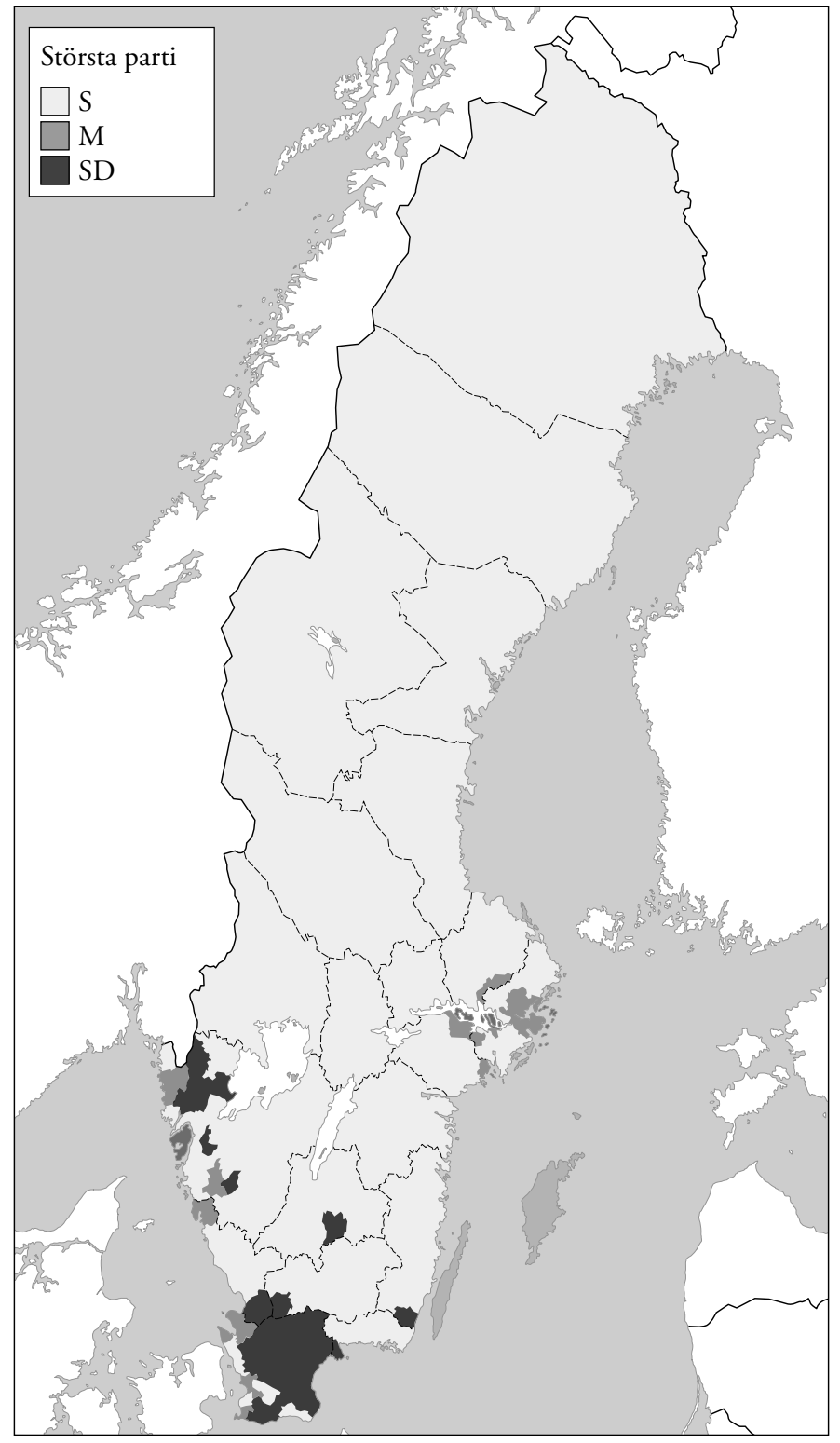


Socialdemokratin kom till Sverige via Tyskland och Danmark, och de danska kamraterna tjänade som förebilder för den första generationen av svenska reformister. Men från och med mitten av i930-talet var svenskarna allmänt erkända som bäst i klassen. De socialdemokratiska regeringarna var under åren 1932-1976 utomordentligt framgångsrika som reformregeringar: de var försiktiga, väl förberedda och tog steg för steg. De kunde peka på full sysselsättning, en blomstrande öppen ekonomi som var konkurrenskraftig på världsmarknaderna, en generös välfärdsstat och ett relativt jämlikt samhälle, som 1980 hade den lägsta inkomstoch könsojämlikheten i världen. LO:s förslag om löntagarfonder 1976 var kanske det mest långtgående konkreta initiativet till en socialistisk ekonomi som någonsin tagits av traditionella socialdemokrater. Landets socialdemokratisering var så genomgripande att den borgerliga koalitionen under åren 1976-1982 inte avvek från den fulla sysselsättningens och de sociala rättigheternas politik. ${ }^{\text {I }}$

\section{Motreformationen}

Det var den socialdemokratiska ledningen som själv inledde den socioekonomiska motreformationen i början av 1980-talet. Den nyliberala vändningen började som ett slags krishantering. Exportindustrin blev mindre konkurrenskraftig. De återstående textil- och konfektionsproducenterna sopades bort, koreanska och japanska företag konkurrerade slutligen ut svenska varv, och stål- och skogssektorn tvingades skära ned. Vinstnivåerna var låga och det var även investeringsnivåerna. Betalningsbalansen visade underskott under åren 1978-198I, och vinstandelen av förädlingsvärdet föll från 30 procent på i960-talet och i början av 1970-talet till 24 procent 1978. Detta framställdes som ett hot mot jobben trots att sysselsättningsnivån upprätthölls mitt under den internationella krisen. Socialdemokraterna och LO-ekonomerna var överens om att lönerna måste pressas ner och vinsterna pumpas upp. Det viktigaste verktyget för att åstadkomma detta var en I6-procentig devalvering så snart Socialdemokraterna åter kom till makten 1982. Partiledningen

I. De borgerliga partierna segrade då tack vare Centerpartiets förkastande av kärnenergi och var upptagna med att hantera energifrågan i en splittrad koalition. 
beskar förslaget till löntagarfonder på varje reell omvandlingsmöjlighet även om en urvattnad version officiellt antogs som en symbolisk gest mot parti- och LO-kongresserna (för en detaljerad redogörelse, se Pontusson 1987).

Under 1980-talet bevittnade man ett internationellt genombrott för nyliberal ekonomi. En grupp socialdemokratiska ekonomer bildade ett seminarium för att lära sig mer om de nya idéerna från Chicago och lyckades fånga Kjell-Olof Feldts och riksbankschefens öron. Marknadsorientering och inflationskontroll blev nya prioriteter för den socialdemokratiska politiken. $1985 \mathrm{drev}$ denna krets igenom en avreglering av Sveriges kredit- och kapitalmarknader. Feldt rapporterade att när han presenterade förslaget för Olof Palme svarade denne: "Gör som ni vill. Jag begriper ändå ingenting" (Feldt I99I, s. 260). Dessa beslut, jämte omorganiseringen av den tröga aktiebörsen i Stockholm, öppnade slussarna för spekulativt finanskapital, både utländskt och inhemskt. Det samlade börsvärdet steg från $\mathrm{I} 2$ procent av BNP I980 till 68 procent I989 och I28 procent 20I2, då det var större än motsvarande tal i de ledande "aktieägarvärdeländerna": IIs procent för USA och I23 procent för Storbritannien (Hedberg \& Karlsson 20I6, s. 2I4). Detta framkallade i sin tur en hemodlad finanskris I99I, som gjorde slut på den fulla sysselsättningen i Sverige, minskade BNP med 4 procent och kostade skattebetalarna ytterligare 4 procent av $\mathrm{BNP}$ i en räddningsoperation för bankerna.

Socialdemokratin hade turen att en borgerlig koalition - ledd av kalla krigs-höken Carl Bildt - satt vid makten från I99I till I994 och tvingades hantera konsekvenserna av denna spräckta finansbubbla. Den uppgiften klarade den inte alls av så att SAP åter kom i regeringsställning 1994, med 45 procent av rösterna. ${ }^{2}$ Socialdemokraterna lyckades återstabilisera ekonomin och befria landet från beroendet av bankirerna i New York. Men operationen var bara lyckad på kort sikt och genomfördes med

2. Bildt var en aggressiv förespråkare för 1990-talets NATO- och EU-expansionism och slogs särskilt för införlivning av de baltiska staterna - även om det var en socialdemokratisk regering under Ingvar Carlsson som tog Sverige in i EU. Efter en tid i internationella institutioner och tankesmedjor och på högst lönsamma ledande poster i finans- och it-bolag återkom Bildt som hårdför utrikesminister i moderatledda koalitionsregeringar under 2006-20I4. 
stränga åtstramningsmetoder utan omprövning av privatisering, marknadsanpassning eller new public management - för att inte tala om avsaknaden av jämlikhetsambitioner. I stället har de borgerliga och socialdemokratiskt ledda koalitioner som har skiftat vid makten sedan I99I fungerat som stafettlöpare i främjandet av ojämlikhet och vinstjakt. De har tillsammans avskaffat skatterna på arv, förmögenhet och fastigheter, gjort kapitalinkomster mindre beskattningsbara än arbetsinkomster och skärpt villkoren för erhållande av sociala förmåner. För två år sedan förklarade Forbes att "Sverige ligger högst upp på listan över de bästa länderna att driva företag i 20I7", och syftade alltså på ett land styrt av socialdemokrater (Forbes 2I december 20I6).

Den ekonomiska ojämlikheten har vuxit. Ojämlikheten i disponibel inkomst har ökat med 60 procent sedan 1980 - från en Ginikoefficient på o,20 till en på o,32 år 2013 - som fört landets inkomstfördelning bakåt till den som rådde på 1940-talet eller kanske till och med slutet av 1930talet. Två tredjedelar av den ökningen kan hänföras till politiska beslut med avseende på skatter och sociala transfereringar och bara en tredjedel till en mer ojämlik fördelning av marknadsinkomsterna. Den nuvarande svenska inkomstfördelningen har vissa likheter med den engelska I688. Den genomsnittliga medlemmen av den rikaste o, I procenten har en disponibel inkomst som efter skatter och transfereringar är trettioåtta gånger större än medelinkomsttagarens. Vid tiden för den ärorika revolutionen hade Englands "världsliga lorder" (aristokratin) en trettio gånger större inkomst än de urbana köpmännen (Maddison 2007, s. 278-279). Förmögenhetsfördelningen har blivit ännu värre och visar upp det mest ojämlika mönstret i Västeuropa, jämförbart med det som råder i länder som Brasilien, Sydafrika eller USA (Crédit Suisse 20I7, tabell 6-5). 2002 ägde Sveriges rikaste I procent I8 procent av hushållens samlade förmögenhet; 2017 hade siffran stigit till 42 procent. ${ }^{3}$

3. Komparativa förmögenhetsfördelningar är svårare att beräkna än komparativa inkomstfördelningar. Men data om Sveriges extraordinära förmögenhetskoncentration tycks vara tämligen robusta. Se till exempel den främste svenske experten på området, Daniel Waldenström (Lundberg \& Waldenström 20I6). Enligt siffror från SCB har landets fattigaste 30 procent ingen nettoförmögenhet alls, bara nettoskulder (i praktiken har de fattigaste 60 procenten ingen nettoförmögenhet alls). Mer dokumentation om den svenska motreformationen återfinns i Therborn 2017 och 2018. 
Andra ojämlikheter fördjupas också. Skolverket har funnit att en färdedel av skolbetygen nu kan tillskrivas föräldrarnas klasstillhörighet, en uppgång från I6 procent 1998. Klassklyftorna efter utbildningsbakgrund när det gäller förväntad livslängd för en trettioåring har vidgats sedan 2000 med två år för kvinnor och ett för män och upp till sex år kortare livslängd för båda könen jämfört med de högst utbildade. Ojämlikheten mellan könen är ett undantag och har inte ökat. Framstegen från 1968 och den feministiska rörelsens kamp har inte rullats tillbaka och utövar fortfarande sin verkan på ett grundligt sekulariserat land utan en betydande religiös höger. Det innebär inte att Sverige har befriats från manlig dominans och chauvinism. Men det innebar att den internationella metoo-rörelsen när den nådde Sverige tog sig uttryck i en rad landsomfattande kollektiva protester mot sexuella trakasserier ledda av kvinnliga professionella, inklusive poliser, akademiker, läkare, jurister och bankanställda.

\section{Faktorer}

Hur kan denna vändning mot allt djupare ojämlikhet, som omintetgör mer än ett halvt århundrade av gradvis utjämning, ha kommit till? Den postindustriella, globaliserade och finansialiserade kapitalismen har en inneboende tendens att öka den ekonomiska ojämlikheten genom att försvaga arbetets position, fragmentisera arbetarklassen och avkvalificera delar av den genom förskjutningar i efterfrågan på arbetskraft - för att inte nämna öppningen av nya perspektiv för kapitalet genom omlokalisering till låglöneländer utomlands - och ökningen av möjligheter till finansiella klipp. Men man hade kanske förväntat sig att det socialdemokratiska Sverige skulle tillhöra de länder som kunde vara bäst i stånd att motstå och tygla sådana tendenser. Tvärtom har ojämlikheten ökat mer i Sverige än i de flesta västeuropeiska länder. Det tycks finnas tre stora skäl till den överraskande utvecklingen under de tre senaste decennierna.

Den viktigaste faktorn har kanske varit den socialdemokratiska ledningens byte av inriktning med ett åsidosättande av varje meningsfullt intresse för ojämlikhet och social rättvisa. Ett belysande exempel är pensionsavtalet som framförhandlades i hemlighet mellan den socialdemo- 
kratiska regeringen och de borgerliga partierna under 1990-talet och antogs av riksdagen 1998. Huvudidén var att göra förmånerna beroende av förändringar i BNP och demografiska trender. Avsikten var att göra systemet mer hållbart under ekonomiskt och demografiskt tryck - ett rationellt mål efter den svenska finanskraschen i99ı. Men de kalkylerande och kohandlande experterna brydde sig inte om fördelningskonsekvenserna av den nya pensionsstrukturen. Det visade sig femton år senare att systemet hade skapat en högre grad av relativ pensionärsfattigdom än EU-genomsnittet: 17 procent mot I4 procent. I Danmark är den 8-9 procent. ${ }^{4}$ I en annan uppgörelse, om skatter 199I, införde den socialdemokratiska regeringen lägre skattesatser för kapitalinkomster än för inkomster av arbete. 2004 avskaffade den all beskattning på arv och gåvor. ${ }^{5}$ Krishantering och tillväxtstimulans trängde undan andra ekonomiska angelägenheter. Svensk socialdemokrati har alltid ägnat stor uppmärksamhet åt det förra men tidigare balanserat detta med motsvarande upptagenhet av social trygghet och jämlikhet.

För det andra handlade det om en intensiv och välfinansierad offensiv från näringslivets sida, som först utvecklades i motstånd mot (och som hämnd för) arbetarrörelsens framgångar under 1970-talet. 1976 satte Svenska Arbetsgivareföreningen (SAF) för första gången i sin historia en storföretagsledare (Curt Nicolin) i ledningen; hans företrädare hade i modern tid alla varit ämbetsmän eller kvasiämbetsmän från handelskammare. Två år senare grundade SAF sin egen propagandabyrå, Timbro, Sveriges första betydelsefulla tankesmedja. I oktober 1983 iscensatte organisationen den kanske största offentliga demonstrationen i svensk historia mot förslaget om löntagarfonder, med inhyrning av 60 järnvägsvagnar, 200 bussar och till och med flygplan för transporter av demonstranter till Stockholm. (En av huvudorganisatörerna ${ }^{6}$ rådgjorde med en studentledare från 1968 om hur protesten skulle iscensättas.) Offensiven var smart nog att inte anta en explicit antifacklig hållning i ett land med

4. Relativ fattigdom råder då den disponibla inkomsten är mindre än 60 procent av medianvärdet för samtliga i befolkningen. Se SCB 2017.

5. Enligt Leif Pagrotsky var avskaffandet av arvsskatten en gåva till det svenska näringslivet från Göran Persson som gottgörelse för hans oförmåga att i 2003 års folkomröstning få in Sverige i euroområdet. Sandberg 20I7, s. I25-I26.

6. Peje Emilsson, offentligt muntligt meddelande på Institutet för framtidsstudier 2018. 
hög facklig anslutningsgrad och en robust tradition av klassamarbete. Den föresatte sig i stället att försvaga fackföreningsrörelsen med subtila medel, till exempel genom att göra det dyrare att vara medlem i facket och att kvalificera sig för den fackliga arbetslöshetsförsäkringen, som de borgerliga regeringarna gjorde. Affärseliten förespråkade en individualistisk, nyliberal ideologi och engagerade sig i en kraftfull lobbyverksamhet, framför allt i skattefrågor med hot om att förmögna affärsmän skulle lämna landet om de inte fick som de ville. Stämningen var hög på Industriförbundets personalfest 1992, där skatteavdelningen framförde en triumferande rap:

\author{
Vi intrigerar \\ och infiltrerar \\ i statsrådsberedning, näring, finans \\ Ja säg den miljö där vi inte finns \\ Riksskatteverket och rättsliga nämnder \\ Håller vi i med kraftfulla händer ...7
}

I den kampanjen mötte de inget motstånd. Juridikprofessorn och skatteflyktsexperten Göran Grosskopf kunde 2010 beskriva landet som "ett skatteparadis" för de rika (Dagens Industri I mars 20Io).

De borgerliga regeringarna hade under åren 199I-1994 och 2006-20I4 inga betänkligheter mot att låta ojämlikheten växa, de sänkte bolagsskatterna ännu mer och avskaffade fastighetsskatten helt och hållet samtidigt som de begränsade tillträdet till arbetslöshets- och sjukförsäkringen och andra förmåner och öppnade den offentliga sektorn för privat spekulationskapital. (De var tillräckligt smarta för att inte bara sänka skatterna för de rika.)

Den tredje faktorn bakom den växande ojämlikheten - framför allt den ojämlika förmögenhetsfördelningen - har varit dynamiken i den högteknologiska exportsektorn, uppblåst av den globaliserade aktiemarknaden. Efter att länge ha varit koncentrerad till Ericsson har den på senare tid gett upphov till en rad framgångsrika it-uppfinnare som snart blev väldigt rika: Skype, Spotify och dataspel som Candy Crush och Minecraft kommer alla från Sverige. Private equity-företag, den mest

7. Ur dåvarande chefen för skatteavdelningens memoarer, Lodin 2009, s. I87f. 
aggressiva formen av finanskapital, är ovanligt väl utvecklade i Sverige: i förhållande till BNP ligger de näst högst i Europa efter Storbritannien (Westerberg 2017).

\section{Nationella berättelser}

Den allt hårdare klasspolariseringen i det svenska samhället har inte gått obemärkt förbi. De kommunala styrena i Stockholm, Göteborg och Malmö har upprättat kommissioner för att undersöka bostadssegregation, hälsotillstånd, utbildning och ekonomisk ojämlikhet. LO har bildat en arbetsgrupp som ska utreda förutsättningarna för jämlikhet och rapportera till kongressen 20I9. Under det senaste året har jag haft äran att få leda ett analytiskt-politiskt projekt, "Klass i Sverige", tillsammans med det fackliga idéinstitutet Katalys, som hittills har publicerat ett tjugotal rapporter och en bok: Kapitalet, överheten och alla vi andra (Therborn 20I8). De kommunala rapporterna och kanske ännu mer Katalysprojektet har fătt viss medial uppmärksamhet. Men föreställningen om Sverige som ett djupnande klassamhälle förblir begränsad till en måttligt växande bred vänster, det vill säga från vänsterorienterade SAP-och LO-medlemmar till Vänsterpartiet, och en ganska liten oberoende-vänstersinnad mediesfär. Den har inte kommit upp på den centrala politiska scenen.

Det finns två huvudskäl till denna dövhet från de flestas sida inför den stigande ojämlikheten. Utan en radikal inre omvandling av sina strukturer skulle det vara svårt för SAP-ledningen, eller till och med för LO-ledningen, att anamma en kritisk klassdiskurs på grund av den tydliga socialdemokratiska delaktigheten i motreformationen. Klassfrågor blir bara ämnen för facklig utbildning som undantag från regeln. Socialt är de nya klassklyftorna och de orättvisor de leder till inte omedelbart märkbara för den genomsnittlige löntagaren, som åtnjutit en reell stegring av lönen efter det att den senaste finanskrisen klingat av. Prekariatet som växer fram på arbetsmarknaden förblir alltför svagt och splittrat för att höja sin röst, även om LO-ledningen uppmärksammade dess situation på senaste första maj. De växande klyftorna i förväntad livslängd kommer inte att visa sig för de drabbade förrän det är för sent att göra 
något åt det. Den ökande ojämlikheten i utbildning och de försämrade livschanserna för gemene man på grund av ackumuleringen av ärvda förmögenheter kommer att bli synliga först för nästa generation.

Den dominerande berättelsen hävdar i stället att Sverige har blivit ett samhälle som hotas av invandringen. I den versionen av händelserna är invandrarna landets huvudproblem, vilket erinrar om den under mellankrigsperioden allmänna tyska föreställningen om att die Juden sind unser Unglück ("judarna är vår olycka") som skapade grogrund för nazismen. I dagens Sverige är det borgerliga språket något mer polerat än i I920- och 1930-talets Tyskland (eller till och med dagens Bayern - "invandringen är alla problems moder", säger Merkels inrikesminister Horst Seehofer från CSU). Enligt Ulf Kristersson är "integrationen" en faktor som förenar "många av de problem vi har i Sverige". Detta återkommande kampanjtema - "ödesfrågan" - är ett tyst erkännande av att det nyliberala programmet med skattesänkningar och ytterligare privatiseringar, som fortfarande står på Alliansens program, inte längre utövar någon allmän lockelse.

Under vintern och våren 2018 var Socialdemokraterna och de fyra borgerliga partierna ense om att invandrarna och deras "integration" var det stora politiska problemet som landet stod inför och tävlade om att vara bäst på att hantera det. De spelade därmed på hemmaplan för främlings- och invandringsfientliga Sverigedemokraterna, som steg i opinionsmätningarna. Det partiet var uppenbarligen den mest "trovärdiga" kraften när det handlade om att slå ned på invandringen. Socialdemokraterna insåg sedan sitt misstag och började argumentera för att riksdagsvalet 2018 i grunden handlade om socialpolitik, eller välfärden, som fortfarande är förbundet med positiva konnotationer i Sverige. Allteftersom kampanjen fortskred lutade Socialdemokraterna mot vänster och krävde vinsttak i offentlig sektor, angrep Alliansens förslag till skattesänkningar, presenterade planer för högre skatter på kapital och lovade mer generösa sociala förmåner av olika slag. Denna vändning i kampanjen lönade sig till slut i meningen att den allmänt förutspådda katastrofen hejdades. Genomsnittliga opinionssiffror på 23-25 procent blev en väljarsiffra på 28 procent, vilket återbekräftade Socialdemokraternas ställning som landets största parti och räddade huvudet på Stefan Löfven. 


\section{Invandring och främlingsfientlighet}

Sverige var, i likhet med större delen av Europa, historiskt ett utvandringsland, där människor flydde i massiv skala från fattigdom men också från religiös eller politisk förföljelse. Etniska minoriteter - huvudsakligen finnar och samer - var små, nedtrampade och föremål för tvångsassimilering. I slutet av 1930-talet mobiliserade studenter och en borgerlig opinion mot att Sverige tog emot ett tiotal judiska läkare som flytt från Nazityskland, och under kriget innebar svensk "neutralitet" att den socialdemokratiskt ledda samlingsregeringen bevarade hjärtliga relationer med Berlin. Men 1943, efter Stalingrad, hjälpte svenska myndigheter och medborgare danska judar att undkomma hotet om deportering till Tyskland genom att organisera transporter över Öresund.

Efter kriget, och särskilt från 1960-talet, var Sverige öppet för en betydande arbetskraftsinvandring, mest från Finland men även i viss mån från Sydeuropa. På 1970-talet tog landet relativt friktionsfritt emot politiska flyktingar från Latinamerika. En ny våg av invandrare kom i början av 1990-talet med Jugoslaviens sammanbrott, som sammanföll med I99I års finanskris. Men då hade situationen förändrats. Rasistiska och främlingsfientliga rörelser hade börjat organisera sig, framför allt i Skåne. En liten aktivistgrupp, kallad Bevara Sverige svenskt (BSS), inledde sin verksamhet 1979, och i Sjöbo hölls 1988 en folkomröstning om mottagande av flyktingar där två tredjedelar av de röstande ställde sig negativa till detta. Samma år bildade BSS-anhängare och andra ett extremt högerparti med nynazistiska element, Sverigedemokraterna. Från I99I till 1994 satt ett främlingsfientligt, nyliberalt parti, Ny demokrati, i riksdagen. Det kollapsade snart trots en alltmer aggressiv linje.

Sverige uppfattade sig efter andra världskriget som ett land präglat av universalism och internationell solidaritet. Både FN och utvecklingsbistånd hade allmänt stöd. Olof Palme fick med sig regeringen och partiet i motståndet mot det amerikanska kriget i Vietnam. Den svenske ambassadören i Chile, Harald Edelstam, blev 1973 en nationell hjälte, i paritet med Raoul Wallenberg, för att han hjälpte människor att undkomma militärdiktaturens dödspatruller. I början av 2000-talet tog Sverige emot många flyktingar från det destruktiva amerikanska 
kriget i Irak och även från konflikterna på Afrikas horn och (senare) från Afghanistan. ${ }^{8}$ Södertäljes kommunalråd Anders Lago vittnade i amerikanska kongressen, med såväl stolthet som oro, om att staden tog emot fler flyktingar från kriget i Irak än hela USA. Föga förvånande var Sverige, jämte Tyskland, den enda frivilliga mottagaren av vågen av flyktingar från Syrien och Afghanistan 2015, då landet tog emot mer än I60 ooo flyktingar. 2017 var nästan 19 procent av Sveriges invånare utlandsfödda, II procent födda i Asien eller Afrika.

Sveriges öppna flyktingpolitik mötte visserligen motstånd från en rasistisk och främlingsfientlig grupp på ytterkanten men hade allmänt stöd. Tidens stämningar uttrycktes av flera statsministrar: 2014 uppmanade Fredrik Reinfeldt svenskarna att "öppna sina hjärtan” för flyktingarna och året därpå förklarade Stefan Löfven att "vi bygger broar, inte murar". Enligt European Social Survey hade de nordiska länderna och i synnerhet Sverige den mest positiva synen på invandring av samtliga europeiska länder (Storm 20I8, tabell I). Men Sverige har nu faktiskt ett stort främlings- och invandrarfientligt parti i Sverigedemokraterna. Partiet kom in i riksdagen 2010 med 5,7 procent av rösterna, vilket steg till I2,9 procent i valet 20I4. Opinionsundersökningarna visade växande stöd för Sverigedemokraterna när (främst) syriska flyktingar kom till landet 2015 men detta sjönk året därpå. I riksdagsvalet 2018 vann de 17,5 procent av rösterna och blev största parti i två av landets valkretsar, med 29 respektive 26 procent av rösterna. Båda dessa låg i Skåne, där Sverigedemokraterna blev största parti i tjugo av trettiotre kommuner med röstsiffror från 25 till 33 procent.

Vad är det som händer i Skåne? En viktig bidragande faktor är dess närhet till Danmark, med sina strömningar av grov småborgerlig populism och främlingsfientlighet. Skåne upplevde yttringar av båda fenomenen under 1980-talet, innan Sverigedemokraterna trädde fram på scenen. Det framgångsrika och numera respektabla Dansk Folkeparti har utgjort

8. Sedan början av århundradet har Sverige också blivit en del av "flyktingskapandet" genom sitt deltagande i USA:s och NATO:s krig mot de asylsökandes hemländer, om än mer i lojalitet mot imperiemakten än som en större förstörelsekraft. Svenska styrkor deltog i ockupationen av Afghanistan från 2002 och i NATO:s krig mot Libyen 201 . Trots Saudiarabiens och Förenade Arabemiratens krig mot Jemen säljer Sverige fortfarande vapen till dem. 
en modell för dem, även om Sverigedemokraterna är mer konservativa och har direkta nynazistiska rötter till skillnad från det danska partiet. Som gränsprovins till kontinenten via Östersjön är Skåne inträdesporten för många invandrare (även om Stockholmsområdet har en större andel utlandsfödda invånare). Det är också en region med stora ojämlikheter där flera kommuner i postindustriellt förfall gränsar till rika och förmögna områden. Lägre stöd för Sverigedemokraterna i liknande städer och samhällen längre norrut speglar den gradvisa utvecklingen av en spridningsprocess med vissa paralleller till socialdemokratins utbredning från Skåne i slutet av i8oo-talet. Men Sverigedemokraterna har en tydlig landsbygdsprägel: de skånska kommuner som undkommer dess grepp är Malmö, Helsingborg och Lund samt rika, konservativa villaförorter.

Trots inbrytningar längre norrut i årets val förblir Sverigedemokraterna knutet till Sydsverige och främst landsbygden. I riksdagsvalet klarade det sig relativt dåligt i storstäderna - Io procent av väljarna i Stockholm och I4 i Göteborg men 17 procent i Malmö - och i universitetsstäderna, med I2 procent i Lund och Uppsala och 9 procent i Umeå. De flesta av Sverigedemokraternas väljare kom från den traditionella högern: 42 procent var före detta moderata väljare, I6 procent kom från de övriga allianspartierna, 23 procent hade tidigare röstat på Socialdemokraterna och bara 5 procent hade ett förflutet i Vänsterpartiet eller Miljöpartiet. En av åtta sverigedemokratiska väljare hade inte röstat tidigare. ${ }^{9}$

Den nuvarande ledningen för Sverigedemokraterna tog över partiet 2005 och rensade det från öppen nynazism. Men sådana böjelser hittar man fortfarande bland dess lokala politiker, som gärna uttrycker mordiska fantasier i sociala medier om att montera upp en kulspruta på Öresundsbron, ta livet av en socialdemokratisk politiker, att en färja med flyktingar ska sjunka och så vidare. Det har funnits två faser i Sverigedemokraternas uppgång. Fram till och med valet 2014 var förbittring bland socioekonomiska "förlorare" den främsta drivkraften bakom dess framgångar. Skåne drabbades särskilt hårt av krisen i början av 1990talet. De som levde på bidrag drabbades återigen under finanskrisen 2008 beroende på att den borgerliga regeringskoalitionen gynnade den

9. Jylhä, Rydgren \& Strimling 20I8, deras data kommer från en stor enkät genomförd i februari och april 2018. 
sysselsatta befolkningen och samtidigt skar ned på välfärdsförmånerna. Inkomsterna för den fattigaste tredjedelen av befolkningen sjönk mellan 2008 och 2013. Under de åren vann Sverigedemokraterna i oproportionerligt hög grad anhängare och framför allt aktivister och lokalpolitiker bland långvarigt arbetslösa, förtidspensionerade och marginaliserade egenanställda arbetare (Folke, Persson \& Rickne 20I8).

Under den andra fasen, från valen 2014 fram tills nu, exploaterade Sverigedemokraterna en bredare social oro för invandringen och gjorde betydande inbrytningar i arbetarklassen, varav en färdedel röstade på partiet 2018 (SVT:s vallokalsundersökning, SVT Valu 20I8). Enligt opinionsundersökningarna nådde stödet för partiet en topp på nästan 20 procent i november 20I5, strax efter inflödet av flyktingar, sjönk sedan till Is procent för att stiga igen under 20I8. Två faktorer tycks ligga bakom den senaste förändringen. En var vändningen hos Moderaterna, som gjorde "integrationen" av invandrare till den stora politiska valfrågan. Den andra var den moralpanik som piskades upp genom mediernas rapportering om gängkrig och en rad skjutningar. Arbetarna hade ett tredje skäl till oro. Inom exempelvis transporter och byggande har EUföretag försökt undergräva arbetsmarknaden genom att ta in lågbetalda arbetare från utlandet (inklusive arbetare från länder utanför EU, till exempel thailändska byggnadsarbetare).

Mellan 40 och 50 procent av de sverigedemokratiska väljarna, det vill säga cirka 8 procent av den totala svenska befolkningen, tycks vara direkta rasister eller främlingsfientliga: människor som inte vill ha en invandrare till granne eller inte vill att en invandrare gifter in sig i deras familj (Jylhä, Rydgren \& Strimling 20I8). Den traditionella etiketten "högerpopulism" passar inte så väl in på Sverigedemokraterna. Partiet rider inte på en våg av demagogisk retorik, med våldsamma angrepp på etablissemanget och vilda löften till folket. Dess ledare är inte en folkuppviglande talare utan en hal typ, cool och strategiskt smart. Partiet framställer sig självt som "socialkonservativt", stående på "nationalistisk grund". Trots partiets lockelse för protestväljare ur arbetarklassen betraktar de flesta av dess anhängare sig som höger.

Sveriges universalistiska politiska kultur fortsatte att manifestera sig i den hållning som de traditionella borgerliga partierna intog till Sverige- 
demokraterna; de tvekar fortfarande i fråga om att bilda en högerregering med stöd från främlingsfientliga krafter. Det svenska politiska landskapet består av ett rödgrönt block, en borgerlig allians mellan fyra partier och Sverigedemokraterna isolerade för sig. Sverigedemokraterna uppvaktar Alliansen, framför allt dess mest kulturellt högersinnade element, Moderaterna och Kristdemokraterna - hittills utan framgång på det nationella planet. Alliansen kan till och med komma att splittras i den frågan, eftersom Centerpartiet och Liberalerna i skrivande stund fortfarande förkastar idén om en regering med stöd från Sverigedemokraterna.

I riksdagsvalet 2018 fick Socialdemokraterna 28,3 procent av rösterna (en minskning med 2,7 procent sedan förra valet). Miljöpartiet fick 4,4 procent (en minskning med 2,5 procent) och Västerpartiet 8 procent (en ökning med 2,3 procent). Det var avgörande för de parlamentariska manövrerna efter valet att det rödgröna blocket förblev något större än Alliansen med 40,7 procent gentemot 40,2 procent och I43 platser i riksdagen mot I42. Med I7,5 procent av rösterna vann Sverigedemokraterna 62 mandat i riksdagen. Detta ledde till en besvärlig parlamentarisk situation. Den rödgröna koalitionen röstades bort av Alliansen och Sverigedemokraterna. Men vad händer sedan? Socialdemokraterna försöker locka in Liberalerna och Centerpartiet - som har deklarerat att de inte vill regera med stöd av Sverigedemokraterna - i en ny koalition. Dessa båda partier, som står längst till höger i det ekonomisk-politiska spektrumet, har hittills visat en viss motståndskraft mot idén om samarbete med Sverigedemokraterna. Något slag av arrangemang med Socialdemokraterna ska inte uteslutas.

\section{Arbetarrörelsens kris}

Det svenska valet erbjuder ytterligare ett exempel på den djupa kris som har drabbat den klassiska europeiska socialdemokratin. Men innan man försöker göra någon svepande generalisering är det viktigt att komma ihåg att denna kris, som också omfattar det italienska kommunistpartiet (som upplöstes 199I) och det franska kommunistpartiet, inte är universell. Framgången för de portugisiska socialisterna och deras vänsterallians och för Corbyns och Sanders kampanjer kräver mer utförlig analys. 
Det finns breda krisframkallande tendenser, men det visar sig också att dessa kan konfronteras på olika sätt med ytterst skiftande resultat. De fyra viktigaste utvecklingstendenserna som framkallar politiska kriser för socialdemokratin tycks vara avindustrialiseringen, söndervittringen av de institutionella och organisatoriska strukturer som har sina rötter i industrisamhället, nya vågor av invandring och en illusorisk konsensus inom eliten att ekonomisk tillväxt och de existerande formerna för välfärdsstaten har gjort sociala reformer och social rättvisa irrelevanta.

Avindustrialiseringen har reducerat arbetarklassens historiska kärna transportarbetare och tillverkningsarbetare sysselsatta i stora företag - och åstadkommit en förödande ekonomisk jordbävning i industrikapitalismens sociala landskap. 1982 utgjorde industriarbetarna 20 procent av den svenska valmanskåren medan de 2014 bara svarade för 9 procent. Samtidigt sjönk andelen "övriga arbetare" från 24 till 20 procent (Vestin \& Oskarson 2017). Sverige har vid en internationell jämförelse tyglat dessa ekonomiska störningar väl genom en nationell sammanhållningspolitik, om än inte i samma utsträckning eller med samma framgång som Norge. I Norrland, där industrin står starkare och den fackliga anslutningsgraden är högre, förblir SAP dock det dominerande partiet trots betydande förluster till Sverigedemokraterna i senaste valet.

Socioekonomiska störningar, nya kommunikationstekniker och nya former av mobilitet har söndrat, och i vissa fall praktiskt taget upplöst, folkliga gemenskaper och deras organisationer (partier och fackföreningar) och kultur. Svenska industristäder och industrisamhällen har upplevt en urholkning av sin tidigare rika och täta arbetarklasskultur. Men 6I procent av arbetarna och 73 procent av tjänstemännen är fortfarande fackligt anslutna. ABF är verksamt över hela landet även om det numera huvudsakligen erbjuder hobbykurser och undervisning i främmande språk. 1982 identifierade 60 procent av de svenska väljarna sig med ett politiskt parti. 2014 hade den siffran sjunkit till 27 procent. 1956 hade II procent av väljarna bytt partipreferens sedan förra valet; 1968 var siffran I9 procent, 198230 procent, och 2018 hade den stigit till 40 procent (Oscarsson \& Holmberg 20I5; SVT Valu 20I8).

Arbetarklassens stöd för SAP började undergrävas på allvar efter partiets högervridning under I980-talet. Mellan I982 och I99I rasade dess 
andel av arbetarklassrösterna från 70 till 57 procent. Det parti som då gynnades av detta var det tydligt främlingsfientliga Ny demokrati. Efter en kortvarig återhämtning 1994 kom ytterligare ett fall efter valet 2006, då väljare främst förlorades till Moderaterna som med sitt fokus på frågor om sysselsättning och det vidgande gapet mellan dem som hade arbete och dem som inte hade det nästan fördubblade sitt stöd inom arbetarklassen mellan 2006 och 20Io. Dessa nya arbetarklassröster för Moderaterna gick sedan till Sverigedemokraterna och gav dem framgångar i valet 2014 (Hedberg 20I5).

2018 fick Socialdemokraterna lite mindre än en tredjedel av arbetarklassens röster medan det rödgröna blocket vann 44 procent totalt, en minskning från 56 procent 2014 och 7I procent 2002. Det var första gången i modern svensk historia som högerpartierna fick en majoritet av arbetarklassens röster, med cirka en tredjedel för allianspartierna och en fjärdedel för Sverigedemokraterna (SVT Valu 20I8). Socialdemokraternas nedgång under det senaste decenniet har inte följt en linjär bana. Arbetarklassens stöd för partiet har fluktuerat i SCB:s två gånger årligen genomförda undersökning av partisympatier: från 52 procent i november 2013 ned till 33 procent i november 20I5, upp igen till 39 procent i november 2017 innan det rasade till 29 procent i maj 2018.

\section{Migrationspolitik}

Den nya vågen av internationell (och interkontinental) migration har skapat en särskild samling problem i Europa, som under ett halvt årtusende varit globalt centrum för utvandring, expansion, erövring och strävanden att omvända anhängare av andra religioner än kristendomen. När Europa härskade över haven var det inte tal om "integration av invandrare”. De få européer som went native föraktades snarare än hyllades i Europa. De utarmade ättlingarna till de tidigare erövrade folken färdas nu till länder bebodda av ättlingar till deras erövrare. Denna nya migratoriska vändning, som har påskyndats av en rad USA-ledda krig i Europas södra bakgård från Afghanistan till Libyen, skapar ett reellt problem för europeisk socialdemokrati, vars traditionella väljargrupper nu finner sig starkt utmanade av ett inflöde av fattiga människor och 
för vilken sociala rättigheter och social rättvisa alltid främst har haft ett nationellt omfång.

Under den nästan överallt förekommande rasismens epok ropade arbetarrörelsen i bosättarländer stolt slagord som "Ena världens arbetare för ett vitt Sydafrika" (i den sydafrikanska gruvarbetarstrejken 1922) eller "Bevara Australien vitt" (den första punkten i det australiska Laborpartiets program). Hur ska den europeiska arbetarrörelsen under den officiella "postrasismens" epok hantera de massor av fattiga invandrare som knackar på gränsportarna? Den svenska fackföreningsrörelsen stödde reglerad arbetskraftinvandring på 1960- och 1970-talen. Nu tycker den att den bara ska tillåtas undantagsvis. Den stöder också den mer restriktiva flyktingpolitik som har anammats efter 20I5 samtidigt som den fortfarande accepterar rätten till asyl. Dess stora oro gäller europeiska byggföretag som tar in sin egen underbetalda arbetskraft. Den fackliga ledningen har drivit en väldigt aktiv kampanj mot Sverigedemokraterna - om än med begränsad effekt utanför de stora industriarbetsplatserna - och några fackföreningar har förbjudit medlemmar i partiet att inta ledarpositioner i facket. Alla de fattiga invandrarna utgör förvisso en allvarlig utmaning för de progressiva partierna. Men svängningarna i politiskt stöd för främlingsfientlighet visar att omfattningen av denna utmaning $i$ hög grad är politiskt beroende.

Medan det ofta hänvisas till de tre första tidigare nämnda krisframkallande faktorerna förblir den fjärde vanligen obemärkt. I själva verket ställs den ofta på huvudet med argumentet att ekonomisk tillväxt och den redan existerande välfärdsstaten har gjort social rättvisa och sociala reformer överflödiga jämte de partier som stöder detta. Denna mittenillusion att de stora sociala frågorna har lösts så att vi lugnt kan segla framåt i välstånd under anpassning till de globala marknadernas vindar har visat sig vara felaktig i flera val. En sådan självbelåtenhet har resulterat i nederlag för och misstro mot etablissemangets politiker. Vid sidan om ökande ojämlikhet och ojämn geografisk spridning av den ekonomiska tillväxten ser vi också vad som kan kallas blemmor eller skavsår i välfärdsstaten. I valet 2018 var de fyra viktigaste frågorna för väljarna sjukvård, utbildning, jämställdhet och social välfärd. Lag och ordning, äldreomsorg och ekonomin rankades lägre medan flyktingar 
och invandring hamnade långt ned på listan (SVT Valu 20I8). Listan var huvudsakligen densamma 2014.

Socialdemokraterna lyckades förskjuta väljarnas uppmärksamhet bort från fokuseringen på invandring, vilket faktiskt hejdade framåtmarschen för främlingsfientligheten. Men social välfärd var inte utan vidare en vinnande fråga för SAP. Det framfördes många klagomål om köer i sjukvården och långa avstånd till sjukhusen i Norrland. Även om Sverige inte har varit föremål för en åtstramningspolitik som kan jämföras med den som de konservativa har drivit i Storbritannien var de resurser som ställdes till förfogande otillräckliga för de växande kraven från en åldrande befolkning. I Norrland anklagades regionala socialdemokratiska politiker för att vara döva eller okänsliga för folkliga behov av vård. I Region Norrbotten, som länge har varit ett starkt fäste för Socialdemokraterna och Vänsterpartiet, blev Sjukvårdspartiet största parti. Sverigedemokraterna försökte också utnyttja orättvisorna i välfärden med påståenden om att resurserna var otillräckliga på grund av att pengar spenderades på flyktingar. Socialdemokraterna förlorar inte stöd därför att deras uppdrag att genomföra sociala reformer nu är klart, utan straffas snarare för att de har övergivit en uppgift som är i stort behov av uppgradering och upprustning. ${ }^{\text {IO }}$

I diskussionen om socialdemokratins kris bör man också uppmärksamma dess motståndskraft mot sådana utmaningar och utrymmet för en framväxande ny vänster. Denna motståndskraft har ekonomiska, sociokulturella och politiska dimensioner. Den ekonomiska dimensionen handlar huvudsakligen om landets plats i världssystemet, särskilt den utsträckning i vilken det är sårbart för globala marknadssvängningar och press från kreditgivare eller hindras av underutveckling. Sverige intar, i likhet med Nordvästeuropa i allmänhet, en stark position i det avseendet, med åtminstone tidigare ett visst försprång som en öppen ekonomi präglad av jämlikhet, högt skattetryck och stark facklig anslutningsgrad som kunde konkurrera framgångsrikt på världsmarknaderna.

IO. Stockholmare har sett detta på nära håll i skandalen med Nya Karolinska, ett fall av offentlig-privat samverkan som trots motstånd från alla de professionella organisationerna har drivits igenom av ideologiskt motiverade borgerliga politiker och en hord av konsulter ledda av Boston Consulting Group och blivit en kloak av korruption och vänskapstjänster. 
Socialt bär Sverige, trots den aktuella vandalismen, fortfarande på ett bestående reformarv. Det finns inga städer eller hela regioner som är ekonomiskt förhärjade. Principen om medborgarnas sociala rättigheter är fast förankrad. Även om massinvandringen har satt den svenska arbetsmarknaden under press har denna klarat sig ganska väl, med en sysselsättningsgrad för utlandsfödda män ( 78,4 procent) som är högre än genomsnittet för alla män, infödda såväl som utlandsfödda, inom EU. Utlandsfödda kvinnor har samma sysselsättningsgrad (67,4 procent) som båda könen räknade tillsammans inom EU. ${ }^{\text {II }}$ Den sedan efterkrigstiden rådande orienteringen mot universalism och internationell solidaritet består alltjämt och gör det svårt för de traditionella borgerliga partierna att bilda en regering med stöd från den främlingsfientliga högern, som deras motsvarigheter i de andra nordiska länderna redan har gjort. Avståndet mellan Sverige och de andra nordiska socialdemokratiska partierna och särskilt det danska har vuxit på senare år.

Den svenska socialdemokratin har en mycket mer gynnsam position i partisystemet än sina systerpartier på andra håll i Europa, framför allt utanför Norden. Den behöver inte konfrontera ett eller två stora borgerliga partier, utan står mot en splittrad mångfald av mindre högerformationer. SAP är fortfarande den största politiska kraften i 25 av landets 29 valkretsar, även om det bara är i en enda (Norrbotten) som det fortfarande vinner mer än 40 procent av rösterna. Det är inget storstadsparti, trots att det inför valet 2018 ledde de kommunala styrena i Stockholm, Göteborg och Malmö, utan hämtar sin styrka främst i industriregionerna, med undantag för Skåne. Det är fortfarande huvudsakligen ett arbetarklassparti nära kopplat till en stark fackföreningsrörelse. Även om Socialdemokraterna numera domineras av professionella yrkespolitiker kan de fortfarande knyta an till vanliga människor, inte minst genom Stefan Löfven, tidigare Metallordförande och icke-akademiker, som utstrålar anständighet även om han bär med sig samma internationella förutfattade meningar och fördomar som vilken traditionell europeisk politiker som helst. Löfven visar ibland klassinstinkt men är också en typisk representant för exportindustrins fackliga ledare som engagerar sig i klassamarbete med sina företags bästa för ögonen.

II. Data från Eurostat och SCB:s arbetskraftsundersökning. 


\section{Omgruppering på vänsterkanten?}

Den svenska socialdemokratin befinner sig i stora svårigheter med ett väljarstöd under I9II års nivåer. Men den är inte döende eller håller på att bli politiskt irrelevant. SAP:s centrala position i det svenska politiska systemet har åter bekräftats i de parlamentariska manövrerna efter valet, och det har krupit tillbaka till 30-procentsnivån i efterföljande opinionsundersökningar. Dess senare prestationer och utsikter för framtiden trotsar lättvindiga funderingar om en dödlig kris för socialdemokratin. Men ingen pånyttfödelse av den traditionella socialdemokratin är i sikte, vilket väcker en annan fråga när vi ställs inför dagens högertendenser: Vad finns det för utrymme för vänsteralternativ att träda fram?

Krisen för socialdemokratin kan, som vi har sett i flera länder, kompenseras med framgång för nya vänsterkrafter. Vänsterpartiet tog ett blygsamt steg framåt i valet 2018 och ökade med 2,3 procent till 8 procent av riksdagsrösterna. Det är nu ett medelstort parti i Stockholm, Göteborg och Malmö med I2 till I4 procent av rösterna och med vissa starka kommunala fästen över hela landet. Det är en anständig vänstersocialdemokratisk kraft, stödd på flitiga kommunalpolitiker och en populär partiledare, men utan någon större ideologisk passion eller förmåga till politisk innovation. Med rötterna i en banbrytande eurokommunistisk partikongress 1964, domineras det nu av tjänstemän även om det fick 9 procent av arbetarklassens röster i senaste valet. Det för vidare det politiska arvet från 1968 och har haft ett betydande inflöde av nya medlemmar på senare år. Vänsterpartiet organiserar nu de största förstamajtågen när SAP inte längre förmår mobilisera.

Vi lever i en tid av löst strukturerade rörelser som mobiliserar genom sociala medier och på gatorna. Ibland kan sådana krafter kanaliseras in $\mathrm{i}$ en omvandling av ett existerande parti, som med Corbyns kampanj och Momentum. I andra fall kan de leda till ett nytt slags rörelseparti, som Podemos i Spanien och La France insoumise i Frankrike. I Tyskland står framtiden för den av Sahra Wagenknecht initierade Aufstehenrörelsen fortfarande öppen. Denna började som en ekumenisk samlande kraft och rymmer vänstersocialdemokrater, gröna och vänsteranhängare. En svensk rörelse måste vara av den tyska ekumeniska typen men utan dess 
ARKIV | NR IO | VALET 2OI8

nationalistiska övertoner. Precis som i Tyskland saknas det utrymme för ytterligare ett parti vänster om mitten, och de existerande partierna är så robust institutionaliserade att det inte blir möjligt för något i stil med La France insoumise att resa sig ur deras ruiner. Av samma skäl finns det inga öppna dörrar för vänsteraktivister att kliva in genom och få grepp om en döende organisation som fortfarande har en reell parlamentarisk tyngd, som brittiska Labourpartiet. Det finns inte heller någon grund för en framväxande gräsrotsrörelse som Podemos, åtminstone inte förrän vid nästa ekonomiska kris.

Vad som behövs - och som kan vara möjligt att uppnå - är en bred, icke-sekteristisk rörelse som kan skaka om SAP, Vänsterpartiet och Miljöpartiet, ingjuta ny energi, nya idéer och radikalism och ge förhoppningar och inspiration till progressivt sinnade människor som har blivit besvikna på existerande partier. Det kan läggas till att det i Sverige finns större potential i den progressiva medelklassen än i många andra länder, eftersom denna domineras av fackligt anslutna tjänstemän. Det tornar upp sig en större social strid kring det professionella arbetet - dess etik, kallelse, autonomi och ansvar - som har blivit föremål för allt hårdare angrepp från new public management, privatiseringsivrare och deras konsulttorpeder. Men en sådan utveckling finns för närvarande inte inom synhåll. Så vad resultatet av regeringsförhandlingarna än kan bli kommer den socioekonomiska motreformationen sannolikt att fortsätta och ytterligare rasera vad som var förra århundradets mest framgångsrika demokratiska och jämlika sociala reformpolitik.

Oktober 2018

Översättning: Sven-Erik Torhell 


\section{PS. Januari 2019}

Den överenskommelse som i januari slöts mellan Socialdemokraterna, Centerpartiet, Liberalerna och Miljöpartiet har många likheter med den politik som gjorde slut på den franska socialdemokratin. En brutal ekonomisk-social högergir, som på alla områden, arbetsmarknaden, hyresmarknaden, fastighetsmarknaden, inkomstfördelningen, den offentliga tjänstesektorn, en jämlik vård och skola för alla, överger löntagarnas och prekariatets intressen för kapitalets, arbetsgivarnas, hyreshajarnas, markägarnas, de högsta inkomsttagarnas, arvtagarnas, det skattefinansierade finanskapitalets och konsultbolagens intressen. Liksom i Frankrike erbjuds den mer eller mindre progressiva urbana övre medelklassen ett mått av klimatpolitik och lite mer invandring - men samtidigt hårdare regler för invandrare i landet - vars räkning kommer att skickas till lägre inkomsttagare och icke-ägare av kapital.

För vad den klassiska socialdemokratin en gång för länge sedan kallade "det arbetande folket" är den här uppgörelsen ett slag i ansiktet. Överklassens och överhetens fåvälde breder ut sig ännu mer. De progressiva socialdemokrater och de vänsterpartister som svalde överenskommelsen för att stoppa en (SD-stödd) M-KD-regering med ett mycket mindre extremt budgetprogram och utan parlamentarisk bas för Sverigedemokraternas drömmar om mordbrand och deportationer, kommer nog att ångra sig lika mycket som Macrons rekryter från socialistpartiet.

Men, som jag understrukit ovan, socialdemokratins kris är varken universell eller ensartad. SAP kommer inte att säcka ihop som franska Parti socialiste. Det förras sociala rötter och organisation är fortfarande djupare, dess position i det nationella politiska systemet mera fördelaktig. $\AA$ andra sidan kan man förmoda, att med en gnutta fransk esprit och kampvilja i den svenska arbetarrörelsen hade Löfvens januarikapitulation aldrig kommit till stånd. Den helt ofranska underdåniga tystnaden under de slutna regeringsförhandlingarna var öronbedövande. Utan den hade Centern och Liberalerna fått välja mellan att, åtminstone tills vidare, nöja sig med det klassamhälle som grävts sedan 1980-talet och inte mer, eller att erkänna Sverigedemokraternas värde som stöd för kapitalets och de högsta inkomsttagarnas fortsatta erövringståg. 
Sedan 1930-talets sociala krispolitik har Sverige varit ett världsberömt och beundrat medborgarland av rättigheter, omtanke och omsorg med socialt ansvarstagande politiska ledare. Beundran var inte alltid så välförtjänt, men den har varit seglivad och spridd över kontinenter. Inom landet kom det sociala kontraktet att få en bred bas, som inkluderade Arbetsgivareföreningen, bankirer som Tore Browaldh, industriledare som Erland Waldenström, och en rad borgerliga politiker som Axel PehrssonBramstorp, Bertil Ohlin, Gunnar Helén och Olof Johansson. Dagens svenska kapitalister och borgerliga politiker har uttryckligen gjort sig urarva den borgerliga delen av den traditionen. Och nu spelas den socialdemokratiska delen bort av Löfven, Andersson, Ygeman \& Co.

Det är betecknande att medan SNS (Studieförbundet Näringsliv och Samhälle) - den sista tillflyktsorten för upplyst borgerlighet i Sverige - i sin konjunkturrapport 2019 föreslår höjda fastighetsskatter, så lovar den nya regeringen (punkt 45), att ytterligare sänka skatten på vinster av fastighetsförsäljning. En gång var full sysselsättning en central och fram till I990-talet framgångsrik del av socialdemokratisk politik. Nu har till och med den mera tvetydiga målsättningen om EU:s lägsta arbetslöshet 2020 tagits bort.

Annie Lööf, på vars nåder Löfven är statsminister, har offentligt deklarerat att Margaret Thatcher och den amerikanska ultrahögerideologen Ayn Rand är hennes idoler. Ska Mrs Thatcher vara Sveriges ledstjärna in i 2020-talet - med en före detta Metallordförande vid rodret?

Den närmaste samhällsutvecklingen är ju mer osäker än vädret, så jag har inget pålitligt svar. Men klimatforskarna kan upptäcka långsiktiga utvecklingstendenser, och samhällsvetare kan det också ibland. Sverige rör sig nu bakåt, mot ett digitaliserat ståndssamhälle, mot en förstärkning av överklassens, överhetens och, kanske, den övre medelklassens fåvälde. 


\section{Referenser}

Crédit Suisse (2017) Global Wealth Databook 2017. URL: https:/www.credit-suisse.com/media/assets/corporate/docs/about-us/ research/publications/global-wealth-databook-20I7-en.pdf (I4 februari 20I9)

Feldt, Kjell-Olof (1991) Alla dessa dagar. I regeringen 1982-199o. Stockholm: Norstedt.

Folke, Olle, Torsten Persson \& Johanna Rickne (20I8) "Arbetslinjen och finanskris förklarar SD:s framgångar", Dagens Nyheter 5 september.

URL: https:/www.dn.se/debatt/andra-ej-i-klara-arbetslinjen-och-finanskris-

forklarar-sds-framgangar/ (I4 februari 2019)

Hedberg, Per (2015) Väljarnas partier 20I4, rapport från Valforskningsprogrammet vid Statsvetenskapliga institutionen i Göteborg, 2I oktober.

URL: https://valforskning.pol.gu.se/digitalAssets/I549/I549329_v--ljarnaspartier-20I4.pdf (I4 februari 20I9)

Hedberg, Peter \& Lars Karlsson (2016) "Den internationella och nationella börshandelns omvandling och tillväxt 1963-2013", i Mats Larsson (red.), Stockholmsbörsen på en förändrad finansmarknad. Stockholm: Dialogos.

Jylhä, Kirsti M., Jens Rydgren \& Pontus Strimling (2018) Sverigedemokraternas väljare. Vilka är de, var kommer de ifrån och vart är de på väg?, forskningsrapport från Institutet för framtidsstudier.

URL: https://www.iffs.se/publikationer/if-rapporter/sverigedemokraterna/ (I4 februari 20I9)

Lodin, Sven-Olof (2009) Professorn som blev näringslivstorped. Min tid i skattepolitiken. Stockholm: Ekerlid.

Lundberg, Jacob \& Daniel Waldenström (2016) Wealth Inequality in Sweden: What Can We Learn From Capitalized Income Tax Data?, working paper 22 april från Nationalekonomiska institutionen vid Uppsala universitet.

URL: http://www.uueconomics.se/danielw/Research_files/Capitalized\%20

Wealth\%2oInequality\%2oin\%20Sweden\%20160422.pdf (I4 februari 20I9)

Maddison, Angus (2007) Contours of the World Economy, I-2030 A.D. Essays in MacroEconomic History. Oxford: Oxford University Press.

Oscarsson, Henrik \& Sören Holmberg (2015) Swedish Voting Behaviour, rapport från Valforskningsprogrammet vid Statsvetenskapliga institutionen i Göteborg, 2I oktober. URL: https://valforskning.pol.gu.se/digitalAssets/I548/I548537_swedish-votingbehavior.pdf (I4 februari 2019)

Pontusson, Jonas (1987) "Radicalization and Retreat in Swedish Social Democracy", New Left Review, 165.

SCB (20I7) "Högre andel äldre med låg inkomst i Sverige jämfört med Norden", statistiknyhet från Undersökningarna av levnadsförhållanden (ULF/SILC) 25 oktober. URL: https:/www.scb.se/hitta-statistik/statistik-efter-amne/levnadsforhallanden/ levnadsforhallanden/undersokningarna-av-levnadsforhallanden-ulf-silc/pong/ statistiknyhet/undersokningarna-av-levnadsforhallanden-ulfsilc2/ (I4 februari 20I9)

Sandberg, Erik (20I7) Jakten på den försvunna skatten. Så blev Sverige ett skatteparadis för de rika. Stockholm: Ordfront. 
ARKIV | NR IO | VALET 2018

Storm, Ingrid (2018) "When does religiosity matter for attitudes to immigration? The impact of economic insecurity and religious norms in Europe", European Societies, 20, 4 .

DOI: https://doi.org/I0.1080/14616696.2017.1402I22

Therborn, Göran (20I7) "The 'People's Home' is Falling Down, Time to Update Your View of Sweden", Sociologisk forskning, 54, 4. URN: http://urn.kb.se/resolve?urn=urn:nbn:se:du-26850

Therborn, Göran (2018) Kapitalet, överheten och alla vi andra. Klassambället i Sverige - det rådande och det kommande. Lund: Arkiv förlag.

Vestin, Erik \& Maria Oskarson (20I7) Kompletterande material till "Den svenska klassröstningen på reträtt. Gör ett nytt klasschema någon skillnad?”, Politica, 49, 2. URL: http://politica.dk/fileadmin/politica/Dokumenter/politica_49_2/vestin_och_ oskarson_appendix.pdf (I4 februari 2019)

Westerberg, Hans (20I7) "Goda tider för Stockholms private equity-bolag", Affärsvärlden, 37. 


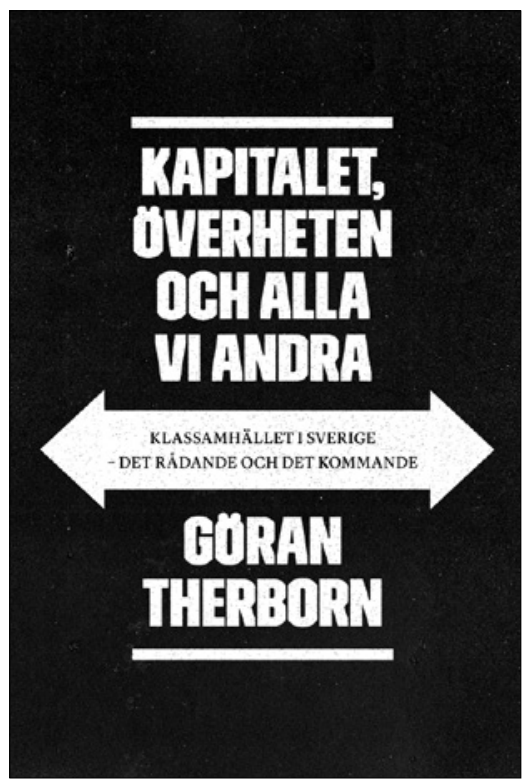

\section{GÖRAN THERBORN TAR SIG AN DEN SKENANDE OJÄMLIKHETEN I SVERIGE}

Kapitalet, överheten och alla vi andra. Klassambället i Sverige - det rådande och det kommande

$$
\text { I76 sidor }
$$

Therborns omtalade uppgörelse med det svenska klassamhället av idag.

\section{OCH I VÄRLDEN}

Ojämlikhet dödar

2I2 sidor

Göran Therborns internationella studie av ojämlikhetens dödliga effekter i såväl fattiga som rika länder (på engelska The Killing Fields of Inequality). Boken placerar in den svenska utvecklingen som tecknas i Kapitalet, överheten och alla vi andra i en global kontext.

Tillsammans skildrar de båda verken på ett klargörande sätt en av vår tids största ödesfrågor.

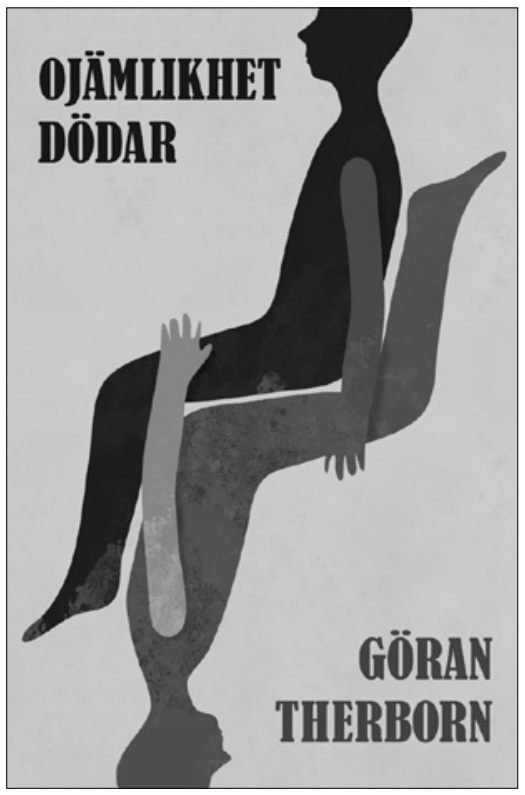

"BÖCKERNA GÅR ATT BESTÄLLA I BOKHANDELN OCH FRÅN WWW.ARKIV.NU“ 


\section{KLASSISK KLASS- FORSKNING I ÅTERUTGIVNING}

GÖRAN THERBORN

Klasstrukturen i Sverige 1930-1980. Arbete, kapital, stat och patriarkat

I78 sidor

Therborns klassiska arbete om den svenska klasstrukturens utveckling under välfärdsepoken publicerades ursprungligen 198r. Den finns sedan 2018 åter tillgänglig i faksimilutgåva som både gratis e-bok och tryckt bok att köpa.

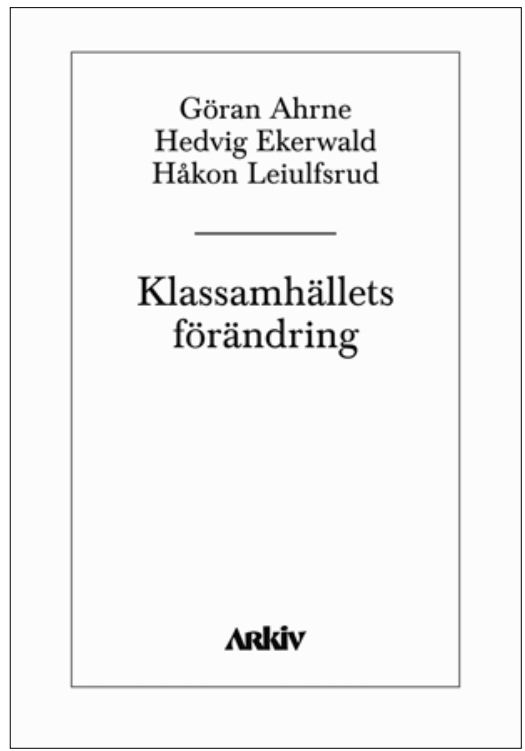

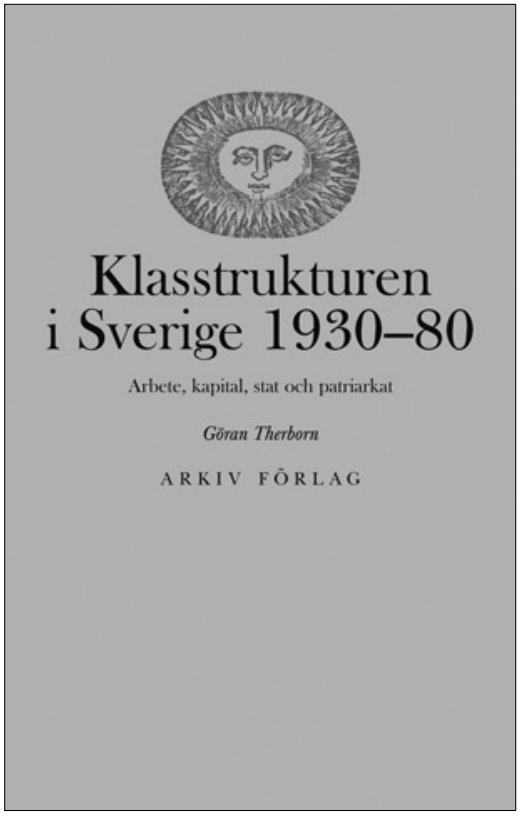

\section{SAMARBETE MED IDÉINSTITUTET KATALYS}

AHRNE, EKERWALD \& LEIULFSRUD Klassambällets förändring I30 sidor

Denna lättillgängliga och inflytelserika klassanalys gavs ursprungligen ut 1985. 2018 års faksimilutgåva återger den fjärde, utvidgade upplagans text från 1995 och finns som både gratis e-bok och tryckt bok att köpa. 